\title{
PENGEMBANGAN MEDIA GAMBAR BERUPA BUKU SAKU FISIKA SMP POKOK BAHASAN SUHU DAN KALOR
}

\author{
Mukarramah Mustari ${ }^{1}$, Yunita Sari ${ }^{2}$ \\ ${ }^{1,2}$ Prodi Pendidikan Fisika, FTK IAIN Raden Intan Lampung; e-mail: mukarramahmustari@ yahoo.co.id
}

Diterima: 20 Januari 2017. Disetujui: 8 April 2017. Dipublikasikan: 28 April 2017

\begin{abstract}
Abstrak: Penelitian ini bertujuan untuk mengembangkan media pembelajaran berupa buku saku fisika dan mengetahui respon peserta didik terhadap kelayakan media pembelajaran berupa buku saku fisika SMP kelas VII pokok bahasan suhu dan kalor. Penelitian ini merupakan penelitian pengembangan dari Brog \& Gall. Subjek penelitian ini adalah peserta didik kelas VII SMP PURNAMA berjumlah 25 peserta didik dan instrumen pengumpulan data berupa angket, diberikan kepada ahli materi, ahli media, dan guru IPA SMP untuk menguji kelayakan media pembelajaran berupa buku saku. Jenis data yang dihasilkan adalah data kualitatif dan kuantitatif yang dianalisis dengan pedoman kriteria kategori penilaian untuk menentukan kelayakan produk. Hasil penelitian yang dikembangkan adalah sangat layak dengan persentase $87 \%$ berdasarkan penilaian ahli materi tahap akhir setelah perbaikan, ahli media dengan persentase $89 \%$ dengan kriteria sangat tinggi, dengan persentase $76 \%$ penilaian guru dengan kriteria tinggi, hasil respon peserta didik dengan persentase $92 \%$ dan $83 \%$ dengan kelompok besar dan kelompok kecil.
\end{abstract}

Kata kunci: buku saku, media pembelajaran fisika, suhu dan kalor.

\section{DEVELOPMENT OF IMAGE MEDIA IN THE FORM OF PHYSICS POCKETBOOK ON TEMPERATURE AND HEAT FOR JUNIOR HIGH SCHOOL}

\begin{abstract}
The research aims to develop learning media in the form of physical pocketbooks and to know the students' response towards the eligibility of learning media in the form of physics Junior High School (SMP) pocketbook class VII subject temperature and heat. This is development research of Brog \& Gall. The subject of this research is the students class VII SMP PURNAMA as many as 25 students, and the instrument of data collecting is questionnaire, given to material experts, media experts, and SMP science teachers to test the eligibility of learning media in the form of a pocketbook. The resulted data types are qualitative and quantitative which analyzed with category scoring criteria to decide the eligibility of the product. The developing research result is very eligible with percentage $87 \%$ based on material expert final after revision, media expert with percentage scoring $89 \%$ with higher criteria, $76 \%$ percent of teachers scoring with higher criteria, the response result of the students is $92 \%$ and $83 \%$ percentage with a big and small group.
\end{abstract}

(C) 2017 Pendidikan Fisika FTK UIN Raden Intan Lampung

Keywords: pocketbook, physics learning media, temperature, heat.

\section{PENDAHULUAN}

Pendidikan adalah suatu proses dalam rangka mempengaruhi peserta didik agar dapat menyesuaikan diri sebaik mungkin dengan lingkungannya, dengan demikian akan menimbulkan perubahan dalam diri individu yang menginginkan untuk berfungsi dalam kehidupan bermasyarakat (Hastuti \& Tiatri, 2012; Subagyo, 2015). Pentingnya pendidikan atau ilmu dijelaskan dalam Al Qur'an surah Al-Mujadalah ayat 11, yang artinya:"Allah akan meninggikan orangorang yang beriman di antaramu dan orang-orang yang diberi ilmu 
pengetahuan." (Al-qur'an dan terjemahnnya, 2008).

Pengertian pendidikan menurut John Dewey (Rostitawati, 2014), pendidikan adalah suatu proses pengalaman. Setiap manusia menempuh kehidupan, baik fisik maupun rohani. Proses pertumbuhan merupakan proses penyesuaian pada tiaptiap phase". Dalam hal ini, pandangan hidup dan tinjauan pendidik terhadap anak didik dan perkembangannya, akan sangat menentukan hasil pendidikan (Ilun, 2013). "Pengertian pendidikan menurut Ki Hajar Dewantoro. Pendidikan adalah daya-upaya untuk memajukan bertumbuhnya budi pekerti (kekuatan batin, karakter), pikiran (intelek) dan tubuh anak untuk memajukn kehidupan anak didik selaras dengan dunianya (Jinan, 2015; Wasty, 1999). Tujuan pendidikan adalah mewujudkan, melaksanakan dan memelihara perkembangan cita-cita kehidupan masyarakat bangsa serta mengarahkan pengalaman belajar kepada mereka (Undang-Undang Republik Indonesia, 2003). Maka dari itu dalam proses belajar kurikulum KTSP Guru dituntut untuk berperan aktif dalam proses belajar di dalam kelas, kreatif dan inovatif (Badan Standar Nasional Pendidikan, 2006). Peserta didik juga harus aktif dalam proses pembelajaran karena pada (KTSP) pelajaran dibuat secara terpadu antara pelajaran yang satu dengan yang lainnya, misalnya pelajaran IPA antara penggabungan fisika, biologi dan kimia.

Tidak terlepas dari masalah pendidikan, seorang guru harus mampu menggunakan media pembelajaran agar peserta didik lebih mudah memahami materi yang guru sampaikan (Azis, 2014). Media pembelajaran merupakan bagian integral dalam sistem pembelajaran. Sehingga dapat menjadi penunjang dalam pembelajaran (Sumiati, 2008).
Pendidikan yang efektif adalah suatu pendidikan yang memungkinkan peserta didik untuk dapat belajar dengan mudah, menyenangkan dan dapat mencapai tujuan sesuai dengan yang diharapkan (Rochmat, 2009). Pendidik (dosen, guru, instruktur, dan trainer) dituntut untuk dapat meningkatkan keefektifan pembelajaran agar pembelajaran tersebut dapat berguna bagi peserta didik (Irwan, Muhammad Padli, 2016).

Keberhasilan proses pembelajaran ditentukan oleh ketiga aspek utama yaitu peserta didik, pendidik (guru) dan sumber belajar (materi), (Oemar, 2013; Tati, 2016). Namun, saat ini yang sering menjadi masalah adalah belum terdapatnya keselaraan antara ketiga aspek dalam proses pembelajaran tersebut (Ramli, 2015). Beberapa bentuk ketidakselarasan ini diantaranya verbalisme, salah tafsir, perhatian tidak berpusat dan terjadinya pemahaman.

Berbagai permasalahan di atas merupakan akibat dari belum optimalnya proses komunikasi dua arah antara pendidik dan peserta didik dalam proses pembelajaran. Kerumitan bahan ajar yang disampaikan semakin membuat peserta didik kurang tertarik untuk membaca buku pelajaran termasuk buku fisika. Dalam pembelajaran IPA khususnya fisika membutuhkan tampilan media gambar sebagai pemahaman peserta didik, agar peserta didik tidak hanya berfikir secara abstrak dan dapat meningkatkan minat belajar peserta didik.

Media pendidikan berupa gambar merupakan media yang paling umum dipakai, gambar merupakan bahasa yang umum yang dapat dimengerti dan dinikmati di mana-mana. Media gambar adalah media yang mengkombinasikan fakta dan gagasan secara jelas dan kuat melalui kombinasi pengungkapan kata-kata 
melalui gambar (Maryani, Martha, \& Artawan, 2013; Yuswanti, 2014).

Salah satu bentuk media pembelajaran yaitu berupa buku saku. Buku saku merupakan buku berukuran kecil yang dapat disimpan dalam saku dan mudah dibawa kemana-mana (Penyusun, 1990). Selain itu, buku saku juga bisa diartikan buku dengan ukurannya yang kecil, ringan, dan bisa disimpan di saku, sehingga praktis untuk dibawa kemana mana, dan kapan saja bisa dibaca (Putri \& Listiyadi, 2014). Dari beberapa pengertian tersebut, buku saku adalah suatu buku yang berukuran kecil yang mana berisi informasi yang dapat disimpan di saku sehingga mudah dibawa kemana-mana.

Buku saku merupakan salah satu alat bantu yang dapat digunakan pada proses pembelajaran (Mutmainah, Daningsih, \& Marlina, 2014). Buku saku dapat digunakan sebagai media yang menyampaikan informasi tentang materi pelajaran dan lainnya yang bersifat satu arah, sehingga bisa mengembangkan potensi peserta didik menjadi pembelajar mandiri.

Sulistiyani \& Nurul Hidayah (2012) mengatakan beberapa hal yang harus diperhatikan dalam menyusun buku saku, antara lain :1) Konsistensi penggunaan simbol dan istilah pada buku saku, 2) Penulisan Materi secara singkat dan jelas, 3) Penyusunan teks materi pada buku saku sedemikian rupa sehingga mudah dipahami, 4) memberikan kotak atau label khusus pada rumus, penekanan materi dan contoh soal, 5) Memberikan warna dan desain yang menarik pada buku saku, 6) Ukuran font standar isi adalah 9-10 point, jenis font menyesuaikan isinya, 7) Jumlah halamannya kelipatan dari 4, missal 12 halaman, 16 halaman, 24 halaman, dan seterusnya. Hal ini dikarenakan untuk menghindari kelebihan atau kekurangan halaman kosong.

Kesimpulan akhir dari beberapa paparan di atas peneliti menganggap perlu untuk melakukan penelitian dan pengembangan dengan judul "Pengembangan Media Gambar Berupa Buku Saku Fisika SMP Pokok Bahasan Suhu dan Kalor". Hal ini diharapkan dapat memberi manfaat bagi pendidik yang belum menggunakan media buku saku dalam menyampaikan materi kepada peserta didik, peserta didik dapat belajar mandiri dan lebih mudah menyerap materi yang dipelajari dan dapat meningkatkan mutu pedidikan.

\section{METODE PENELITIAN}

Penelitian ini menggunakan metode penelitian dan pengembangan (research and development). Penelitian dan pengembangan merupakan proses dan validasi produk pendidikan (Sanjaya, 2013). Model pengembangan dalam penelitian ini menggunakan model Borg and Gall dalam (Sugiyono, 2012) meliputi: 1) Potensi dan masalah, 2) Pengumpulan data, 3) Desain Produk, 4) Validasi desain, 5) Revisi desain, 6) Uji coba produk, 7) Revisi produk, 8) Uji coba pemakaian, 8) Revisi produk, dan 10) Produksi massal. Dalam penelitian ini dibatasi langkahlangkah penelitian pengembangan dari sepuluh langkah menjadi tuju langkah saja dikarenakan keterbatasan waktu dan materi peneliti dalam penelitian. Namun setelah penelitian berlangsung ada respon positif dari guru untuk memproduksi beberapa eksamplar guna tercapainya pembelajaran yang lebih baik lagi dari sebelumnya. Subjek penelitian adalah peserta didik kelas VII SMP PURNAMA yang berjumlah 25 peserta didik. Dan instrument pengumpulan data berupa angket, diberikan kepada ahli materi, ahli media, 
dan guru IPA SMP untuk menguji kelayakan media gambar pembelajaran berupa buku saku.

Persamaan yang digunakan menentukan kelayakan buku saku adalah:

Skor penilaian:

$$
\frac{\text { JumlahTotalNilaiSkor }}{\text { JumlahSkorPadaInstrumen }} \times 4
$$

Setelah memperoleh hasil skor persentase dari penelitian kemudian diinterpretasikan dalam kriteria tabel berikut:

Tabel 1. Kriteria Penilaian untuk Validasi Ahli, Respon Guru dan peserta didik

\begin{tabular}{ccc}
\hline $\begin{array}{c}\text { Skor } \\
\text { Penilaian }\end{array}$ & $\begin{array}{c}\text { Rentan } \\
\text { Skor }\end{array}$ & Klasifikasi \\
\hline 4 & $3,26-4,00$ & Sangat baik \\
\hline 3 & $2,51-3,25$ & Baik \\
\hline 2 & $1,76-2,50$ & Kurang Baik \\
\hline 1 & $1,01-1,75$ & Tidak Baik \\
\hline
\end{tabular}

Sehingga jenis data yang dihasilkan adalah data kualitatif dan kuantitatif yang dianalisis dengan pedoman kriteria kategori penilaian untuk menentukan kelayakan produk

\section{HASIL DAN PEMBAHASAN Hasil}

Hasil pengembangan yang dilakukan pada penelitian ini adalah menghasilkan media gambar berupa buku saku fisika SMP pokok bahasan suhu dan kalor yang valid pada penilaian ahli dan menarik pada respon peserta didik, adapun langkahlangkah dalam mengembangkan media gambar berupa buku saku yang dikembangkan oleh peneliti. Penilaian dari validator ahli materi disajikan dalam Tabel 2, berikut ini:

Tabel 2. Penilaian Validator Ahli Materi

\begin{tabular}{lcccc}
\hline \multicolumn{1}{c}{ Aspek } & $\begin{array}{c}\boldsymbol{\Sigma} \text { (X) Validasi } \\
\text { awal }\end{array}$ & $\begin{array}{c}\text { Skor maks/aspek } \\
\text { validasi Awal }\end{array}$ & $\begin{array}{c}\text { Persentase (\%) } \\
\text { validasi awal }\end{array}$ & $\begin{array}{c}\text { Kriteria } \\
\text { Interpretasi }\end{array}$ \\
\hline Kualitas Isi & 36 & 45 & $80 \%$ & Tinggi \\
\hline $\begin{array}{l}\text { Ketepatan } \\
\text { cakupan }\end{array}$ & 21 & 30 & $70 \%$ & Tinggi \\
\hline Motivasi & 12 & 15 & $80 \%$ & Tinggi \\
\hline Bahasa & 36 & 45 & $80 \%$ & Tinggi \\
\hline Ilustrasi & 11 & 15 & $73 \%$ & Tinggi \\
\hline Evaluasi & 11 & 15 & $\mathbf{4 5 7 \%}$ & Tinggi \\
\hline Jumlah total & $\mathbf{1 2 7}$ & $\mathbf{1 6 5}$ & $\mathbf{7 6 \%}$ & \\
\hline $\begin{array}{l}\text { Persentase } \\
\text { Rata-rata }\end{array}$ & & $\mathbf{T 3}$ & \\
\hline $\begin{array}{l}\text { Kriteria } \\
\text { Interpretasi }\end{array}$ & & $\mathbf{T i n g g i}$ & \\
\hline
\end{tabular}

Berdasarkan hasil validasi ahli materi, penilaian yang dicapai rata-rata tinggi. Jumlah persentase validasi pada aspek kualitas isi adalah $80 \%$ dengan kriteria interpretasi tinggi, pada aspek ketepatan cakupan mencapai persentase $70 \%$ dengan kriteria interpretasi tinggi, pada aspek motivasi persentase $80 \%$ dengan criteria tinggi dan persentase $80 \%$ di capai pada bahasa dengan kriteria interpretasi tinggi pada aspek ilustrasi pesentase di dapat $73 \%$ dengan kriteria tinggi sedangkan pada aspek evaluasi di dapat persentase $73 \%$ dengan criteria tinggi. Hasil validasi ahli materi keseluruhan aspek yang di nilai berjumlah total 127 dengan persentase $76 \%$ sehingga mendapat kriteria interpretasi tinggi.

Hasil rekapitulasi validasi oleh guru SMP Purnama terhadap pengembangan media gambar berupa buku saku fisika smp pokok bahasan suhu dan kalor dapat di lihat pada Tabel 3 berikut, 
Tabel 3. Penilaian Validator Ahli Media

\begin{tabular}{|c|c|c|c|c|}
\hline Aspek & $\begin{array}{c}\Sigma X \text { Validasi } \\
\text { awal }\end{array}$ & $\begin{array}{c}\text { Skor maks/aspek } \\
\text { validasi Awal }\end{array}$ & $\begin{array}{c}\text { Persentase (\%) } \\
\text { validasi awal }\end{array}$ & $\begin{array}{c}\text { Kriteria } \\
\text { Interpretasi }\end{array}$ \\
\hline Kualitas Isi & 14 & 20 & $70 \%$ & Tinggi \\
\hline Bahasa & 14 & 20 & $70 \%$ & Tinggi \\
\hline Konstruktivisme & 53 & 70 & $76 \%$ & Tinggi \\
\hline Ilustrasi & 34 & 40 & $85 \%$ & Sangat Tingg \\
\hline Evaluasi & 15 & 20 & $75 \%$ & Tinggi \\
\hline Penampilan fisik & 8 & 10 & $80 \%$ & Tinggi \\
\hline Jumlah total & 140.899 & 104 & $456 \%$ & Tinggi \\
\hline $\begin{array}{l}\text { Persentase } \\
\text { Rata-rata }\end{array}$ & \multicolumn{4}{|c|}{$76 \%$} \\
\hline $\begin{array}{l}\text { Kriteria } \\
\text { Interpretasi }\end{array}$ & \multicolumn{4}{|c|}{ Tinggi } \\
\hline
\end{tabular}

Berdasarkan Tabel 3, jumlah respon guru secara keseluruhan adalah 140.899, dengan rincian pada aspek isi persentase yang di capai adalah 70\% dengan kriteria interpretasi tinggi, pada aspek bahasa yaitu mencapai $70 \%$ dengan kriteria interpretasi tinggi. Aspek konstruktivisme dan aspek penggunaan ilustrasi mencapai kriteria interpretasi tinggi dan untuk sangat tinggi untuk ilustrasi dengan persentase yaitu $76 \%$ dan $85 \%$. Pada aspek evaluasi pesentase $75 \%$ dengan kriteria tinggi, dan aspek penampilan fisik presentase $80 \%$ dengan kriteria tinggi. Jadi, dapat di simpulkan bahwa media gambar berupa buku saku sudah baik, tetapi masih ada yang perlu diperbaiki lagi sesuai masukan yang diberikan validator agar media gambar berupa buku saku yang dikembangkan oleh peneliti benar-benar valid dan siap digunakan sebagai bahan ajar disekolah.

Setelah desain produk divalidasi melalui penilaian ahli materi dan ahli media serta guru IPA SMP/MTs kelas VII, peneliti melakukan revisi terhadap desain produk yang dikembangkan berdasarkan masukan-masukan ahli tersebut. Saran/masukan untuk perbaikan dapat dilihat pada Tabel 4 berikut,

Tabel 4. Saran/Masukan Perbaikan para Ahli

\begin{tabular}{|c|c|c|c|}
\hline No & Aspek & Saran/masukan untuk perbaikan & Hasil Perbaikan \\
\hline 1 & Kualitas Isi & Memenuhi aspek isi & $\begin{array}{lll}\begin{array}{l}\text { Aspek materi } \\
\text { dipenuhi }\end{array} & \text { sudah } \\
\end{array}$ \\
\hline 2 & Ilustrasi (Gambar) & $\begin{array}{l}\text { - } \text { Peta konsep tidak perlu penjelasan } \\
\text { - } \quad \text { Gambar original }\end{array}$ & $\begin{array}{ll}\text { - } & \text { Peta sudah diperbaiki } \\
\text { - } & \text { Gambar sudah original }\end{array}$ \\
\hline 3 & Bahasa & $\begin{array}{l}\text { Penulisan bagan menggunakan angka } \\
\text { romawi }\end{array}$ & $\begin{array}{l}\text { Penulisan dalam media } \\
\text { gambar berupa buku saku } \\
\text { sudah diperbaiki }\end{array}$ \\
\hline 4 & Motivasi & $\begin{array}{l}\text { Penulisan ayat-ayat Al-Qur'an dalam } \\
\text { media gambar berupa buku saku } \\
\text { perbaiki kembali }\end{array}$ & $\begin{array}{l}\text { Ayat-ayat Al-Qur'an dalam } \\
\text { media gambar berupa buku } \\
\text { saku sudah diperbaiki }\end{array}$ \\
\hline 5 & Evaluasi & $\begin{array}{l}\text { Soal-soal pada alat evaluasi perlu } \\
\text { ditambah }\end{array}$ & $\begin{array}{l}\text { Soal-soal pada alat evaluasi } \\
\text { sudah ditambah }\end{array}$ \\
\hline
\end{tabular}


Secara garis besar hasil uji coba kelompok kecil dan uji coba kelompok besar dapat dilihat pada gambar 1 berikut,

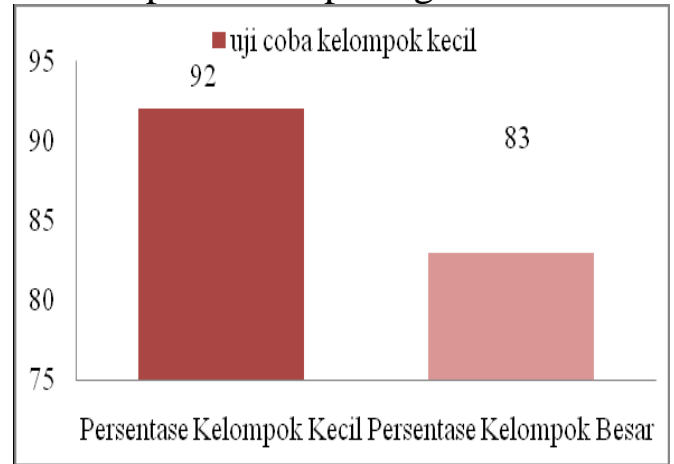

Gambar 1. Grafik uji coba kelompok kecil dan kelompok besar

\section{Revisi Produk}

Setelah dilakukan uji coba kelompok kecil dan uji coba kelompok besar untuk mengetahui kemenarikan media gambar berupa buku saku pembelajaran fisika pokok bahasan suhu dan kalor, produk dikatakan kemenarikannya sangat tinggi sehingga tidak dilakukan uji coba ulang. Selanjutnya media gambar berupa buku saku dapat dimanfaatkan sebagai salah satu sumber belajar bagi peserta didik dan guru di SMP/MTs kelas VII pada Materi Suhu dan Kalor.

\section{Pembahasan}

Penelitian dan pengembangan didefinisikan sebagai studi sistematis terhadap pengetahuan ilmiah yang lengkap atau pemahaman tentang subjek yang diteliti. Penelitian ini diklasifikasikan sebagai dasar atau terapan sesuai dengan tujuan peneliti yaitu untuk mengembangkan media gambar berupa buku saku fisika SMP pokok bahasan suhu dan kalor.

Adapun penelitian pengembangan yang dimaksudkan dalam penelitian ini adalah untuk mengembangkan media gambar berupa buku saku fisika SMP pokok bahasan suhu dan kalor. Untuk menghasilkan produk media gambar berupa buku saku yang dikembangkan, maka peneliti menggunakan prosedur penelitian dan pengembangan yang digunakan adalah model penelitian pengembangan Borg and Gall yang hanya dibatasi sampai tujuh langkah penelitian dan pengembangan, yaitu potensi dan masalah, pengumpulan data, desain produk, validasi desain, perbaikan desain, uji coba produk, revisi produk. Alasan peneliti membatasi hanya sampai tujuh langkah penelitian yaitu karena dengan tujuh langkah penelitian dan pengembangan sudah dapat menjawab pertanyaan yang ada dirumusan masalah.

Pada penelitian dan pengembangan ini validasi dilakukan dua kali, yaitu validasi pertama dan validasi kedua. Hasil validasi pertama dilakukan oleh ahli materi dan ahli media serta praktisi yaitu guru fisika SMP Purnama. Hasil penilaian pada ahli materi pertama mencapai kriteria interpretasi "Tinggi" yaitu dengan persentase rata-rata mencapai $76 \%$, dan hasil validasi materi kedua mendapatkan kiteria interpretasi "Sangat Tinggi" dengan persentase yang diperoleh yaitu $87 \%$. Persentase rata-rata yang dicapai oleh ahli media pertama yaitu $69 \%$ dengan kriteria "Tinggi", dan validasi media kedua persentase yang diperoleh yaitu $89 \%$ dengan krtiteria interpretasi "Sangat Tinggi". Validasi juga dilakukan oleh praktisi yaitu tiga orang guru IPA SMP Purnama.

Berdasarkan hasil rekapitulasi nilai bahwa persentase rata-rata pada validasi praktisi pertama yaitu mencapai $85,7 \%$ dan 91,6 \%, dan validasi praktisi kedua kriteria interpretasi "Sangat Tinggi" dengan persentase yang diperoleh $90,4 \%$ dan 91,6\%. Jadi dapat diketahui bahwa setelah produk diperbaiki sesuai masukan yang diberikan validator produk yang 
dikembangkan peneliti sudah valid dan dapat digunakan sebagai bahan ajar di kelas.

Beberapa referensi/jurnal yang relevan sesuai dengan penelitian yang peneliti lakukan diantaranya: 1.) Penelitian yang dilakukan (Adi, Setyono, \& Dkk, 2013), yang mengembangkan media pembelajaran fisika berupa buletin yang berbentuk buku saku untuk pembelajaran fisika di kelas VIII. Penelitian Yulian menunjukkan bahwa media pembelajaran yang dikembangkan berupa buletin Fisika dalam bentuk buku saku memiliki kriteria sangat baik berdasarkan penilaian dari ahli materi, ahli bahasa dan ahli media memberikan rata-rata penilaian sebesar $86,56 \%$; 2.) Sama halnya penelitian yang dilakukan oleh (Asyhari \& Silva, 2016) juga mengembangkan media pembelajaran berupa buletin dalam bentuk Buku aku untuk pembelajaran IPA terpadu. Hasil penelitian telah dikembangkan media pembelajaran berupa buletin IPA Terpadu dalam bentuk buku saku dengan kelayakan media sangat layak dengan persentase $82 \%$; 3.) (Laksita et all., n.d) Mengembangkan media pembelajaran Fisika dalam bentuk pocket book untuk peserta didik kelas X SMA. Media pembelajarannya berhasil diuji cobakan dalam uji coba lapangan awal dengan hasil baik dan uji coba lapangan utama dengan hasil sangat baik; 4.) beda hal dengan penelitian yang dilakukan oleh Nurul Husna Siregar, penelitian eksperimen untuk mencari pengaruh penggunaan media gambar terhadap kemampuan menulis puisi siswa. Penelitiannya bertujuan untuk mengetahui pengaruh penggunaan media gambar terhadap kemampuan dalam menulis puisi pada siswa 5.) Sementara penelitian yang dilakukan oleh (Qurrota'Aini \& Dkk, 2013), mengembangkan media pembelajaran berupa buku saku untuk meningkatkan motivasi belajar peserta didik. Hasil penelitiannya menunjukan bahwa media buku saku yang dikembangkan berada pada kualifikasi baik dan terdapat kenaikan skor rata-rata motivasi belajar peserta didik secara keseluruhan sebesar 5,64\%, dan 6.) Penelitian yang dilakukan (Ekawati, 2013), beliau mendesain media pembelajaran buku saku yang berbasis mobile application menggunakan Player Air for Android pada Adobe Flash Professional CS 5.5. Penelitiannya berhasil membuat media pembelajaran yang dihasilkan berupa gambar dan materi yang disusun menggunakan adobe flash dan disajikan dalam bentuk buku saku.

Cuplikan temuan beberapa penelitian di atas, menyatakan bahwa penilaian media gambar berupa buku saku layak digunakan sesuai dengan kriteria BSNP (Kesehatan, 2009).

$\begin{array}{cr}\text { Penelitian-penelitian } & \text { sebelumnya } \\ \text { hanya mengembangkan } & \text { media }\end{array}$ pembelajaran berupa buku saku saja atau hanya mengembangkan media gambarnya saja. Sementara dalam penelitian ini selain mengembangkan media pembelajaran berupa buku saku, juga mengembangkan media gambar yang terdapat pada materi Suhu dan Kalor. Dalam penelitian ini mengkolaborasikan antara media gambar yang dipadukan dalam buku saku. Media pembelajaran yang dikembangkan berupa media gambar yang berwarna agar lebih mudah dalam menjelaskan materi suhu dan kalor yang terdapat dalam buku saku. Serta lebih mampu menarik perhatian dan minat belajar peserta didik. Selain itu buku saku yang dikembangkan juga didesain sesuai ukuran kantong baju sekolah peserta didik jadi lebih memudahkan peserta didik untuk membawanya. 
Secara umum hasil penilaian dari validator untuk media gambar berupa buku saku yang dikembangkan hasilnya layak digunakan tanpa revisi. Hasil Penelitian yang diperoleh, diuji cobakan melalui dua tahap yaitu uji coba kemenarikan media gambar berupa buku saku yang bertujuan untuk melihat respon peserta didik terhadap produk yang dikembangkan. Uji coba kemenarikan dilakukan dengan dua tahap yaitu uji kelompok kecil dan kelompok besar. Hasil rata-rata kemenarikan yang diperoleh pada uji coba kelompok besar yaitu $83 \%$ dan untuk uji coba kelompok kecil hasil persentase ratarata yang diperoleh yaitu $92 \%$, ini berarti modul yang dikembangkan dalam kriteria interpretasi kemenarikan yang baik jika digunakan sebagai sumber belajar. Guru disekolah sangat meminta agar media gambar berupa buku saku dapat diproduksi massal minimal 20 buku saku untuk media pembelajaran dan dari pihak peserta didik sangat tertarik terhadap media gambar berupa buku saku sebagian peserta didik sudah membeli untuk sumber belajar. Hasil tersebut menunjukkan bahwa media gambar berupa buku saku yang dikembangkan mendapatkan respon yang positif dari peserta didik dan guru.

Selain itu media gambar berupa buku saku memungkinkan peserta didik menggunakan berbagai sumber pengetahuan untuk menambah pengetahuan, sehingga dapat meningkatkan nilai psikomotor, nilai kognitif dan afektif peserta didik. Jadi secara keseluruhan dapat disimpulkan bahwa media gambar berupa buku saku dapat meningkatkan aktifitas peserta didik dan efektif jika digunakan sebagai media pembelajaran di kelas.

Kelebihan prodak hasil dan pengembangan. Produk hasil pengembangan ini memiliki beberapa kelebihan sebagai berikut ini: a.) media gambar berupa buku saku pembelajaran fisika pokok bahasan suhu dan kalor ini memberikan pengetahuan baru bagi peserta didik; b.) media gambar berupa buku saku dengan materi suhu dan kalor dapat memotivasi peserta didik untuk lebih semangat dalam belajar karena memuat kata-kata motivasi; c.) media gambar berupa buku saku yang dikembangkan mendorong peserta didik untuk belajar secara mandiri dan lebih menarik karena siswa di tuntut untuk lebih aktif dalam kegiatan belajar mengajar (KBM); d.) media gambar berupa buku saku yang dikembangkan disajikan sesuai dengan pembelajaran yang menjadikan peserta didik lebih aktif yaitu dengan metode diskusi; e.) penampilan fisik media gambar berupa buku saku yang dikembangkan memiliki perpaduan warna yang menarik, serta dilengkapi dengan emoticon yang lucu sesuai dengan perkembangan peserta didik SMP.

Kekurangan hasil prodak dan pengembangan. Produk pengembangan penelitian ini memiliki beberapa kelemahan sebagai berikut ini: a.) media gambar berupa buku saku yang dikembangkan hanya pada materi suhu dan kalor; b.) media gambar berupa buku saku pembelajran fisika yang dikembangkan hanya dibatasi pada KD 1.2 dan KD 6.4; c.) media gambar berupa buku saku yang dikembangkan hanya pada sub pokok bahasan pada materi Suhu dan Kalor.

\section{SIMPULAN DAN SARAN Simpulan}

Simpulan yang dapat diambil dari penelitian ini adalah sebagai berikut:

1. Hasil validasi dilakukan oleh ahli materi dan ahli media serta praktisi yaitu guru SMP Purnama. Hasil penilaian pada ahli materi mencapai 
kriteria "Sangat Tinggi" dengan persentase rata-rata yang diperoleh yaitu $87 \%$. Hasil penilaian pada ahli media persentase yang diperoleh yaitu 89\% dengan kriteria "Sangat Tinggi" dan yang terakhir yaitu validasi praktisi yang dilakukan oleh guru SMP PURNAMA, mendapat kriteria "Sangat Tinggi" dengan persentase $90 \%$

2. Respon peserta didik SMP kelas VII terhadap kemenarikan media gambar berupa buku saku pada materi suhu dan kalor yang dikembangkan oleh peneliti baik dalam uji coba kelompok kecil yaitu 12 peserta didik maupun uji coba kelompok besar dengan melibatkan 25 peserta didik termasuk kedalam kategori "Sangat Tinggi". Hal ini menunjukkan bahwa media gambar berupa buku saku yangdikembangkan sangat menarik bagi peserta didik dan dapat digunakan sebagai salah satu media penunjang dalam pembelajaran.

\section{Saran}

1. Penulis mengharapkan hasil penelitian berupa Media gambar berupa buku saku fisika SMP pokok bahasan suhu dan kalor untuk peserta didik SMP/MTs kelas VII dapat digunakan dalam proses pembelajaran disekolah sehingga kualitas media gambar berupa buku saku secara keseluruhan menjadi lebih baik dan bermanfaat.

2. Produk berupa media gambar berupa buku saku yang dikembangkan dilakukan uji coba di satu sekolah yaitu SMP PURNAMA, sehingga diharapkan media gambarberupa buku saku menarik untuk digunakan sebagai salah satu media penunjang dalam pembelajaran.

3. Media gambar berupa buku saku dengan fisika yang dikembangkan hanya pada pokok bahasan suhu dan kalor untuk SMP/MTs kelas VII saja, tetapi media gambar berupa buku saku dapat dikembangkan pada materi IPA fisika lainya. Selain itu untuk menambahkan ayat-ayat Al-Qur'an dengan penafsiran dan maksud yang jelas terkait hubungan ayat dengan materi yang disajikan dalam media gambar berupa buku saku dan kata-kata bijak untuk menumbuhkan motivasi belajar peserta didik harus tepat, bermanfaat, dan tidak membingungkan peserta sebagai pengguna produk.

\section{DAFTAR PUSTAKA}

Adi, Y., Setyono, \& Dkk. (2013). Pengembangan media pembelajaran fisika Berupa buletin dalam bentuk buku saku Untuk pembelajaran fisika kelas VIII Materi gaya ditinjau dari minat baca Siswa. Fakultas Keguruan Dan Ilmu Pendidikan UNS.

Al-qur'an dan terjemahnnya. (2008). Departemen Agama RI. Bandung: Diponegoro.

Asyhari, A., \& Silva, H. (2016). Pengembangan Media Pembelajaran Berupa Buletin dalam bentuk Buku Saku Untuk Pembelajaran IPA Terpadu. Jurnal Pendidikan Fisika AlBiruni.

Azis, A. (2014). Kompetensi Guru Dalam Penggunaan Media Dengan Mutu Pendidikan. Jurnal Pelopor Pendidikan, 5(1), 49-58. Retrieved from

http://www.stkippgrismp.ac.id/jurnalpelopor-pendidikan-3/

Badan Standar Nasional Pendidikan. (2006). Panduan Penyusunan Kurikulum Tingkat Satuan Pendidikan Jenjang Pendidikan Dasar dan Menengah, 1-11.

Ekawati, Y. (2013). Desain Media Pembelajaran Dalam Bentuk Buku Saku yang Berbasis Mobile Application menggunakan Player Air 
for Android pada Adobe Flash Professional CS 5.5 Untuk Materi Fisika SMA. Prosiding Fkip Uns, 4(1).

Hastuti, R., \& Tiatri, S. (2012). Pendidikan Karakter Oleh Guru (Studi Kasus di Sekolah Dasar Islam di Jakarta). Prosiding Seminar Nasional Psikologi Islam, 144-150.

Ilun, M. (2013). Progresivisme John Dewey dan Pendidikan Partisipatif Perspektif Pendidikan Islam. Jurnal Pendidikan Agama Islam, 1(1), 101121.

Irwan, Muhammad Padli, N. (2016). Strategi Pembelajaran Efektif Berbasis Mobile Learning Pada Sekolah Dasar. Jurnal Iqra', 10(1), 114.

Jinan, M. (2015). Pendidikan Karakter Ki Hadjar Dewantar: Studi Kritis Pemikiran Karakter Dan Budi Pekerti Dalam Tinjauan Islam. PROFETIKA (Jurnal Studi Islam), 16(2), 167-180.

Kesehatan, P. T. (2009). Standar Penilaian Badan Standar Nasional Pendidikan.

Laksita, S. V., S., \& Dkk. (n.d.). Pengembangan Media Pembelajaran Fisika Dalam Bentuk Pocket Book Pada Materi Alat Optik serta Suhu dan Kalor Untuk Kelas X SMA.

Maryani, S., Martha, N., \& Artawan, G. (2013). Penggunaan Media Gambar Untuk Meningkatkan Kemampuan Menulis Teks Berita Siswa Kelas VIII SMPN 4 Soromadi Kabupaten Bima NTB. E-Journal Program Pascasarjana Universitas Pendidikan Ganesha, 1(2), 1-15.

Mutmainah, Daningsih, E., \& Marlina, R. (2014). Buku Saku Keanekaragaman Hayati Hasil Investasi Tumbuhan Berpotensi Tanaman Hias Di Gunung Sari Singkawang.

Oemar, H. (2013). Kurikulum dan
Pembelajaran. Jakarta: Bumi Aksara. Penyusun, T. (1990). Kamus Besar Bahasa Indonesia. Jakarta: Balai Pustaka.

Putri, V. C., \& Listiyadi, A. (2014). Pengembangan Buku Saku Sebagai Media Pembelajaran Di Smk Ketintang Surabaya. UNESA, 1-9.

Qurrota'Aini, S. S., \& Dkk. (2013). pocketbook as media of learning to improve students' Learning motivatin. Jurnal Pendidikan Akuntansi, XI(2).

Ramli, M. (2015). Hakikat Pendidik Dan Peserta Didik. Tarbiyah Islamiyah, 5(1), 61-85.

Rochmat, W. (2009). Pembelajaran yang Efektif, Efisien, dan Menarik Sesuai dengan Perkembangan Teknologi Modern. Seminar Pendidikan, 1-11.

Rostitawati, T. (2014). Konsep pendidikan john dewey. Jurnal Manajemen Pendidikan Islam, 2(2), 133-139.

Sanjaya, W. (2013). Penelitian Pendidikan Jenis, Metode dan Prosedur. Jakarta: Kencana.

Subagyo. (2015). Pengembangan Kualitas Sumber Daya Manusia Pegawai Perusahaan Listrik Negara Rayon Tenggarong Kabupaten Kutai Kartanegara. E-Journal Ilmu Pemerintahan, 3(2), 1098-1112.

Sugiyono. (2012). 2012Metode Penelitian Kuantitatif Kualitatif dan $R \& D$. Bandung: Alfabeta.

Sulistiyani, \& Nurul Hidayah, D. (2012). Perbedaan Hasil Belajar Siswa Antara Menggunakan Media Pocket Book dan tanpa Pocket Book pada Materi Kinematika Gerak Melingkar Kelas $\mathrm{X}$.

Sumiati, A. (2008). Metode Pembelajaran. Bandung: Wacana Prima.

Tati, N. (2016). Pembelajaran Psikologi Pendidikan Di Madrasah Ibtidaiyah. Al Ibtida, 3(1), 74-92.

Undang-Undang Republik Indonesia. 
(2003). Undang-undang Republik Indonesia Nomor 20 Tahun 2003. Undang-Undang Sistem Pendidikan Nasional. Retrieved from http://stpibinainsanmulia.ac.id/wpcontent/uploads/2013/04/Lamp_2_UU 20-2003-Sisdiknas.doc

Wasty, S. (1999). Dasar dan Teori Pendidikan Dunia. Malang: Rineka
Cipta.

Yuswanti. (2014). Pengunaan Media Gambar Untuk Meningkatkan Hasil Belajar Siswa Pada Pembelajaran IPS Di Kelas IV SD PT . Lestari Tani Teladan ( LTT ) Kabupaten Donggala. Jurnal Kreatif Tadulako Online, 3(4), 185-199. Retrieved from jurnal.untad.ac.id 